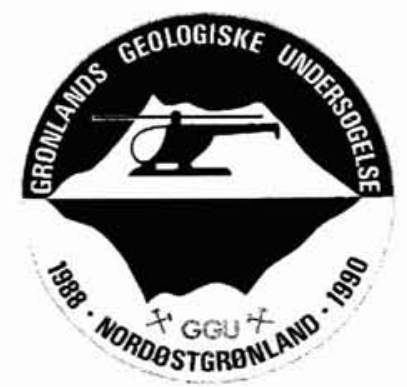

\title{
Stratigraphy of the post-Caledonian sediments in the Germania Land area, North-East Greenland
}

\author{
Stefan Piasecki, Lars Stemmerik, \\ Johan D. Friderichsen and A. K. Higgins
}

\begin{abstract}
Sediment outliers in North-East Greenland are briefly described and dated on the basis of macro- and microscopic plant fossils. Conglomerates and sandstones at Depotnæsset are probably of Late Carboniferous age based on the content of poorly preserved spores and pollen together with Stigmaria molds. Conglomerates, sandstones and coals from localities west of Germania Land are of Early to Middle Jurassic age based on poorly preserved fossil leaves and sporomorphs. The sedimentary facies and the fossil content of the Upper Carboniferous sediments suggest that the transition between the continental Carboniferous basins of East Greenland and the marine basins of North Greenland was situated north of $78^{\circ} \mathrm{N}$. The maturity of the sporomorphs suggests that the Upper Carboniferous basins subsided by $1.5-2 \mathrm{~km}$ in Late Carboniferous to Middle Jurassic time, whereas subsidence of the Jurassic basins was negligible.
\end{abstract}

S. P., L. S., J. D. F. \& A. K. H., Geological Survey of Greenland, Øster Voldgade 10, DK-1350 Copenhagen K, Denmark.

Post-Caledonian sediments were found to be restricted to local fault-bounded outcrops in the area around Germania Land and on Store Koldewey during geological mapping of North-East Greenland north of $76^{\circ} \mathrm{N}$ (Figs 1, 2; Stemmerik \& Piasecki, 1990; Friderichsen et al., 1991). This paper discusses the stratigraphy of the outliers found in Germania Land, near Depotnæsset and north of Annekssøen (Fig. 1). The stratigraphy of the more complete Jurassic-Cretaceous succession on Store Koldewey is not treated here.

Dating of the sediments overlying the basement crystalline rocks in this region is important as it gives some clues to the age of the thick sedimentary sections in the offshore areas (e.g. Larsen, 1990; Fig. 2). Also it gives some indications of the post-Caledonian depositional and tectonic history of this region compared to the better known areas further to the north and south (Fig. 2; e.g. Håkansson \& Stemmerik, 1989; Surlyk, 1990; Stemmerik et al., 1991, 1993).

\section{Carboniferous}

Sediments of Carboniferous age occur east of Fladebugt and west of Depotnæsset (Fig. 1). Both outcrops are associated with faults. The outcrops on the east shore of Fladebugt occur on the north side of a NE-SW trending fault, and east of the projected trace of a major NNWSSE fault which $10 \mathrm{~km}$ farther south in the south-east corner of Fladebugt is characterised by pyrite-mineralised breccias and oil relics in small cavities and late fractures (Christiansen et al., 1991). The sequence has a maximum thickness of about $25 \mathrm{~m}$, and is exposed over an area about 1000 by $500 \mathrm{~m}$ in size; it dips to the south-west at about $25^{\circ}$. It is dominated by mediumgrained white quartz sandstones, which in part comprise massive well-cemented beds forming small cliffs up to $5 \mathrm{~m}$ high, and in part friable poorly cemented sandstones whose weathered debris hides the unconformity with the crystalline basement gneisses. Some beds contain black coaly chips up to $3 \mathrm{~cm}$ in diameter, and a few pebbly, conglomeratic blocks were seen containing imprints of plant stems up to $30 \mathrm{~cm}$ long.

The exposures at Chatham Elv near Depotnæsset occur in a down-faulted position on the east side of a major NNW-SSE trending fault (Fig. 1; Friderichsen et al., 1991). The basal unconformity is not seen but the exposed sedimentary section seems to start not far above the unconformity. The lowest exposed part of the section is a $60 \mathrm{~m}$ thick conglomerate overlain by $15 \mathrm{~m}$ of interbedded conglomerates, sandstone and siltstone. The lowest conglomerate is red-weathering, poorly sorted and clast supported; the boulders are mainly quartz and feldspathic gneisses and amphibolites. The upper $15 \mathrm{~m}$ thick unit consists of stacked fining-upwards sequences of pebbly conglomerate, cross-bedded sandstone and siltstone. The sandstones and siltstones are greenish-grey and coaly 
seams and coal fragments are common in the lower ten metres. Plant fossils are common throughout and include small tree trunks cf. Lepidodendron sp. and Stigmaria roots (Fig. 3).

Age

The occurrence of Stigmaria indicates a general Carboniferous age for the Chatham Elv sediments. A siltstone sample (GGU 361979) from the upper part of the succession was found to contain approximately $1 \%$ TOC. The majority of the organic matter is black and brown woody material (70-80\%); the remaining $20-30 \%$ consists of sporomorphs, cuticula and unstructured organic matter typical for a Type III kerogen. The sporomorphs are generally badly preserved and in many cases classification even within the major morphological groups is du-

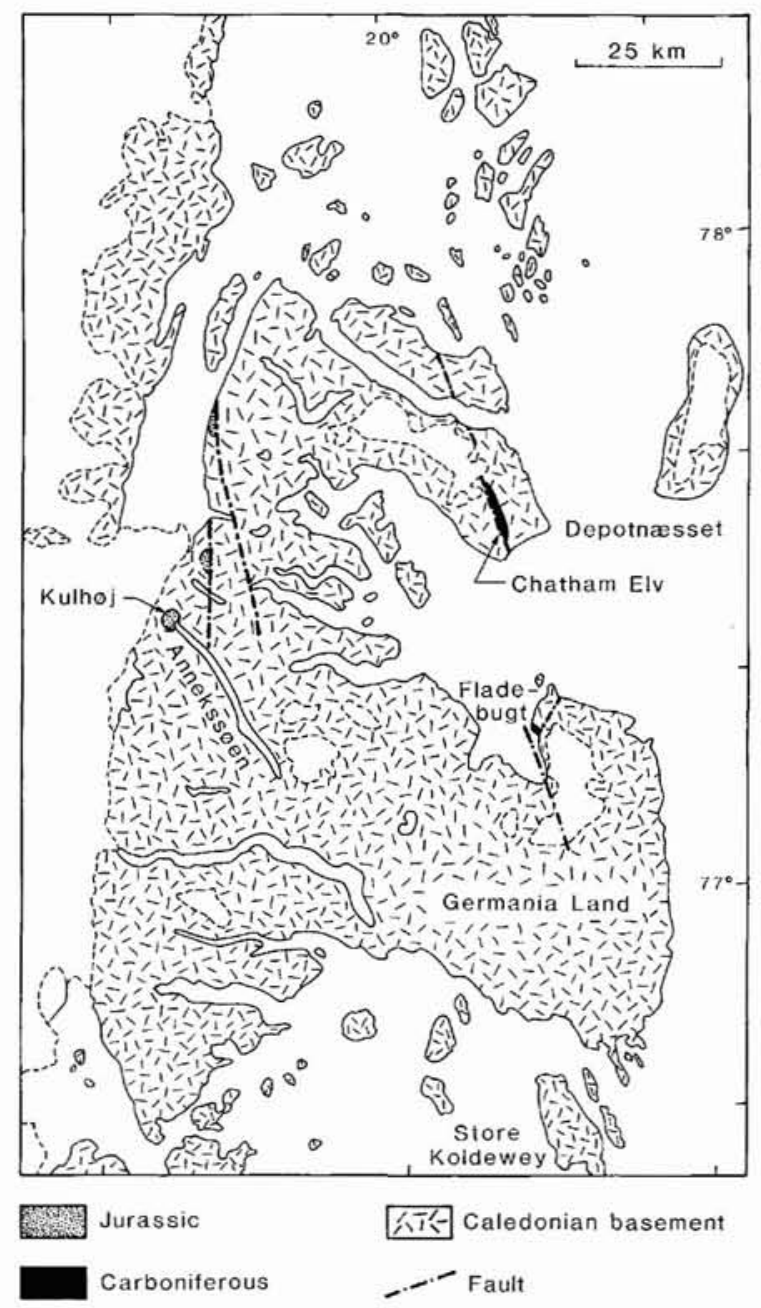

Fig. 1. Geological map of Germania Land and adjoining regions, showing post-Caledonian outcrops. bious. However, both monosaccate and bisaccate pollen are present and trilete spores are frequent; the following forms have been identified:

\section{Spores}

cf. Apiculatisporites sp.

Calamospora sp.

Endosporites sp.

Lophotriletes sp.

Raistrickia saetosa (Loose) Schopf, Wilson \& Bental.

Pollen

cf. Florinites sp. / cf. Potoniesporites sp.

cf. Protohaploxypinus sp.

This sporomorph assemblage indicates a Late Carboniferous age for sample GGU 361979 from Chatham Elv.

The Thermal Alteration Index (TAI) of the sporomorphs is 2; this means that these rocks have been covered by a maximum of $1.5-2 \mathrm{~km}$ of sediments.

\section{Jurassic}

Jurassic sediments have been reported from three localities along the N-S trending fault zone north of Annekssøen (Fig. 1; Koch, 1917; Stemmerik \& Piasecki, 1990; Friderichsen et al., 1991). The sediments are preserved in localities on the down-faulted blocks west of the faults and have thus escaped glacial erosion.

Two different sedimentological units appear to be present: (1) a very coarse-grained clastic facies with terrestrial plant fossils; and (2) fine-grained shales and coals alternating with (?)limestones. There are no field observations that directly connect the two units in age or depositional environment. The two northern localities comprise up to $25 \mathrm{~m}$ of conglomerates and quartzitic sandstones, which unconformably overlie crystalline basement rocks. The base of the unit is not exposed at either locality, but the exposed sections seem to start not far above the unconformity. The lower $5 \mathrm{~m}$ comprise conglomerates with basement clasts and large-scale trough cross-bedded sandstones with fragments of coal and silicified wood. The wood trunks are allochthonous and broken, with a maximum length of $5 \mathrm{~m}$ and a diameter of up to $0.40 \mathrm{~m}$. The following $20 \mathrm{~m}$ consist of fine- to coarse-grained sandstone, with conglomeratic horizons and frequent wood fragments in the upper part. The sediments close to the fault zone are brecciated and hydrothermally pyritised, and in this area also contain wood fragments and imprints of leaves (Jensen \& Stendal, 1994).

The abundant silicified wood fragments appear well preserved with growth rings and sediment-filled drying cracks, but most of the material exposes only mineralised ghost-structures in thin section. A few specimens from 


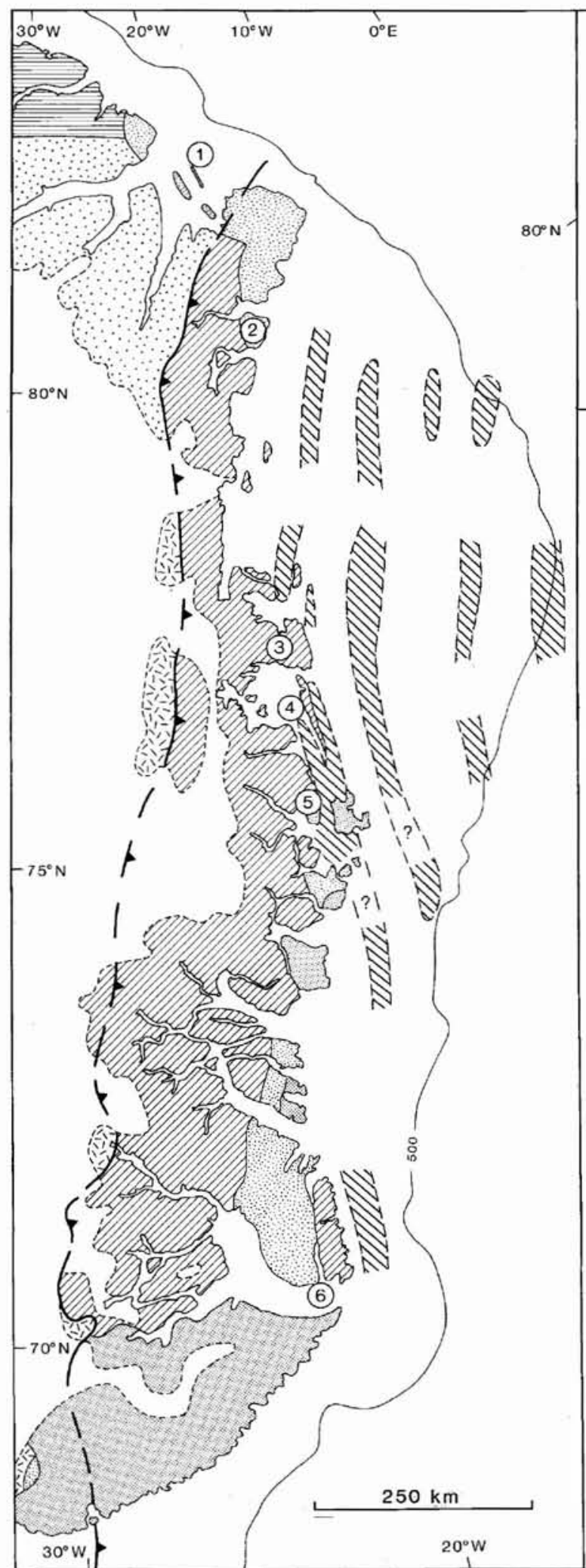

Fig. 2. East and North-East Greenland continental shelf with sedimentary basins (offshore basins from Larsen, 1990).

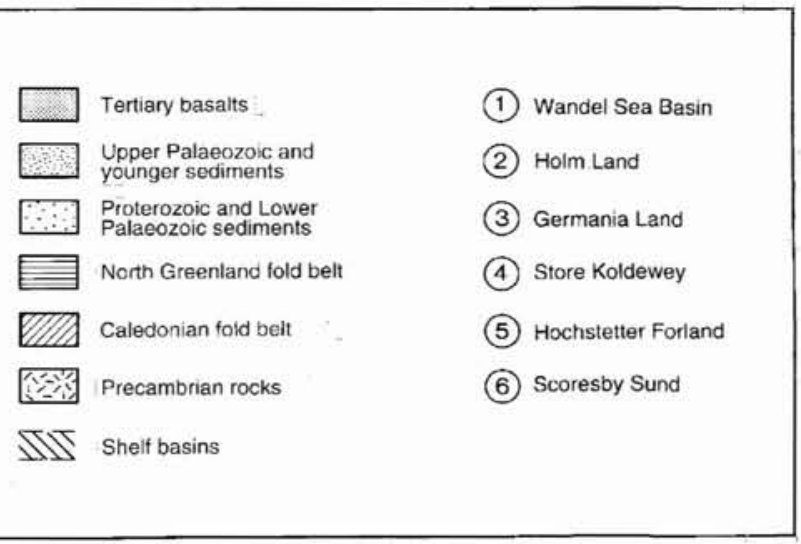

the hydrothermal zone show fine detail of secondary wood structures of growth rings, rays and chamber-pores of clearly gymnosperm affinity. However, high magnification shows that the preservation of the organic cell walls is not sufficiently good for precise identification of genus and species (P. Wagner, personal communication 1991). The imprints of leaves have been identified by B. Eske Koch (personal communication 1990) as specimens of the genus Baiera (Fig. 4) and the flora is comparable to that described by Harris (1935) from the Lower Jurassic of the Scoresby Sund area, central East Greenland.

The following poor assemblage of sporomorphs has been identified from the conglomeratic unit (GGU 365093):

\section{Spores}

Deltoispora minor (Couper) Pocock

Cibotiumspora jurienensis (Balme) Filatoff

Baculatisporites cf. comaumensis (Cookson) Potonié Lycopodiumsporites sp.

Densosporites sp.

cf. Laevigatosporites sp.

Cyathidites concavus Tralau

Contignisporites problematicus (Couper) Döring Pollen

Alisporites robustus Nilsson

Bisaccate indet.

cf. Araucariacites australis Cookson

cf. Perinopollenites elatoides Couper

Cerebropollenites macroverrucosus (Thiergart) Schulz Tsugapollenites $\mathrm{cf}$. dettmannae (Drugg) Tralau

The second type of sedimentological unit is represented by the southernmost Jurassic exposure, near Kulhøj, which was reported by I.P. Koch (1917; fig. 133). Stemmerik \& Piasecki (1990) reported a high density of drifted coal blocks at Kulhøj but the only in situ outcrop occurs in a canyon at the outlet of Annekssøen farther to the east. It is approximately $5 \mathrm{~m}$ thick and consists of 

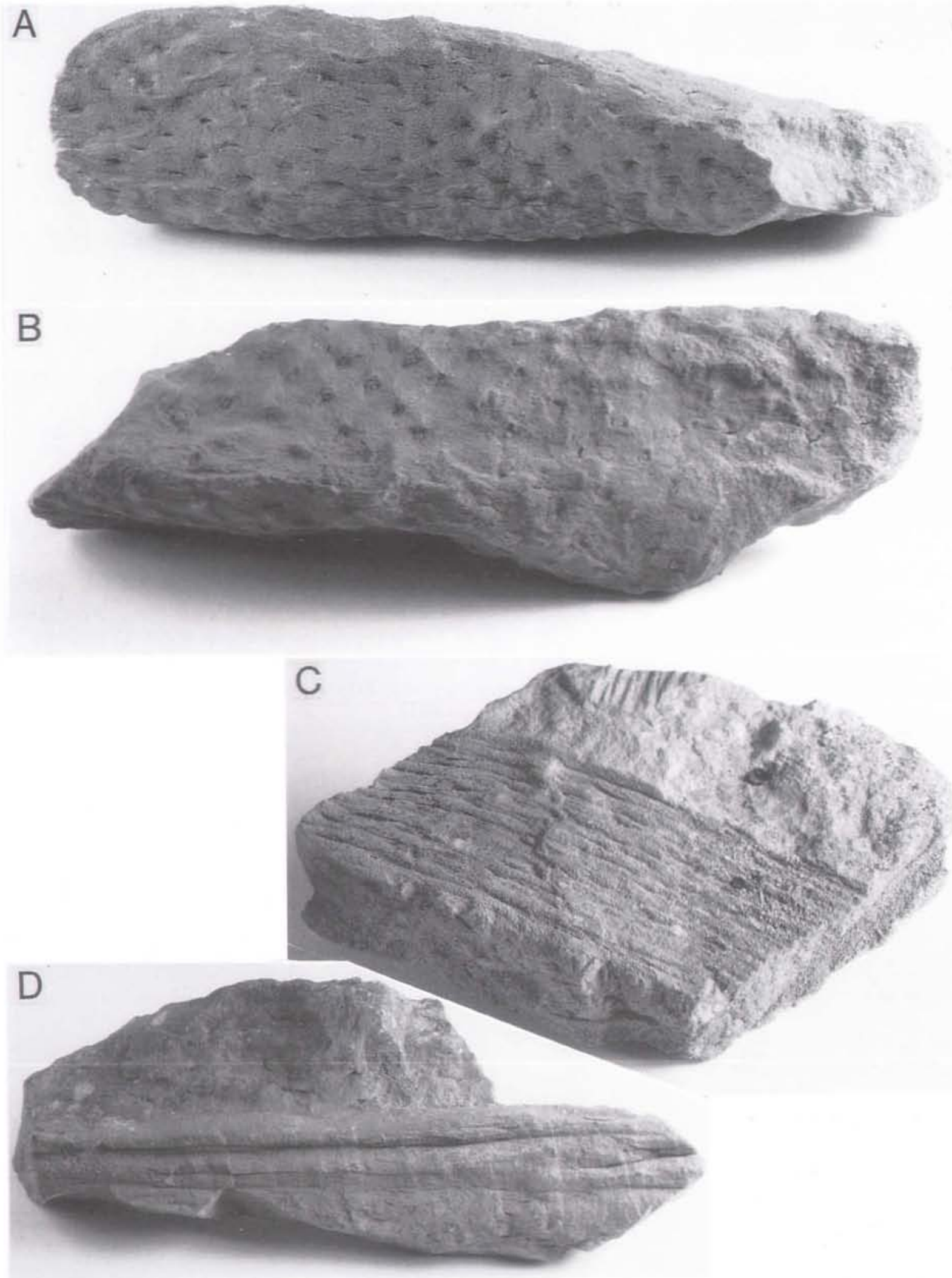

Fig. 3. A \& B: Stigmaria sp. from two sides $(\times 2.7)$ GGU 361980 . C: cf. Lepidodendron sp. $(\times 2.5)$ GGU 361978A. D: unidentified wood impression ( $\times 2.5$ ) GGU 361978B. From the Upper Carboniferous of Depotnasset, Chatham Elv. 
alternating $0.50-0.75 \mathrm{~m}$ thick beds of 'coal and limestones' (Koch, 1917). The base of the unit is not exposed and the depositional relationship to the presumed older, coarse-clastic Jurassic unit is not clear; the exposure is overlain by glacial sediments. The coals are very rich in organic matter with a major component of slender, elongate bodies (Fig. 5). In thin sections and in palynological preparations this material appears very similar to degraded algal bodies. Geochemical and coal-petrographic studies show that the material is resinous (J. BojesenKoefoed, personal communication 1992). Some common orientation of the organic bodies (Fig. 5) may reflect deposition in running water but low content of clastic material and terrestrial organic matter (woody material, cuticulas, spores and pollen) indicate a stagnant environment with a local source for the organic matter. No marine fossils have been recorded in the coals.

These Jurassic coals have excellent potential as source rocks for oil with a Hydrogen Index in the range of 713 to 719. Thermal maturity is low (TAI $2^{-}$; immature).

The coals (GGU 360381) contain a badly preserved and very poor sporomorph assemblage (K. Dybkjær, personal communication 1991) with some species in common with the assemblage noted above.

\section{Spores}

Deltoidospora toralis (Leschik) Lund

Deltoidospora minor (Couper) Pocock

Stereisporites stereoides (Potonié\& Venitz) Pflug

Striatella cf. S. seebergensis (Mädler) Filatoff \& Price Pollen

\section{cf. Araucariacites australis Cookson \\ Alisporites robustus Nilsson \\ cf. Alisporites microsaccus (Couper) Pocock \\ Umbrosaccus cf. $U$. keuperianus Mädler \\ Pinuspollenites minimus (Couper) Kemp \\ cf. Monosulcites sp.}

The age of the coarse clastic sediments is probably Early Jurassic on the basis of the fossil plants (B. Eske Koch, personal communication 1990); the sporomorphs of the sample indicate a broad Early to Middle Jurassic age. The age of the drifted coals is also estimated to be Early to Middle Jurassic on the basis of very badly preserved sporomorphs. Similar coal-bearing sediments in Hochstetter Forland to the south have been dated as Middle Jurassic (not younger than Callovian) on the basis of dinoflagellate cysts.

It is not possible to determine the relative age of the two sedimentological units due to the low diversity of the fossil material and the presence of only long-ranging species.

\section{Regional implications}

Dating of the post-Caledonian strata in the Germania Land area is important because it has implications both for the basins offshore North-East Greenland as well as for the general palaeogeography of the northern North Atlantic (Fig. 2).

The occurrence of Upper Carboniferous fluviatile sediments in this area indicates that this region was part of the East Greenland continental basin during the Late Palaeozoic. Marine Upper Carboniferous strata occur at Holm Land approximately $250 \mathrm{~km}$ to the north. They form part of an extensive marine basin covering the Barents Sea and the margins of North Greenland; the southern limit of the basin is unknown, but this new occurrence of continental Upper Carboniferous deposits indicates that it exists somewhere between latitudes $78^{\circ} \mathrm{N}$ and $80^{\circ} \mathrm{N}$ in the offshore area of the East Greenland shelf.

Several basins with sedimentary successions totalling $10-12 \mathrm{~km}$ in thickness have been identified from gravimetric studies offshore North-East Greenland, whereas the ridges between the basins have a sediment cover thickness in the range of 2-3 km (Fig. 2; Larsen, 1990). Parts of this shelf area were investigated by seismic methods during 1991 (Christiansen \& Pulvertaft, 1992) and the sediments preserved in the Germania Land area provide clues to the stratigraphy and subsidence history of these basins:

- Continental Upper Carboniferous sediments most likely form the oldest part of the sedimentary successions in basins south of $78^{\circ} \mathrm{N}$. The northern limit of the continental Upper Palaeozoic rift basin is situated between latitudes $78^{\circ} \mathrm{N}$ and $80^{\circ} \mathrm{N}$ on the North-East Greenland shelf.

- The onshore basins in Germania Land subsided by $1.5-2 \mathrm{~km}$ in Late Carboniferous to Middle Jurassic time. Post-Middle Jurassic subsidence of these basins was negligible. Although these figures are not directly applicable to the much thicker offshore basins, it is likely that the subsidence history of the offshore basins closest to Germania Land may be comparable.

\section{References}

Christiansen, F. G., Bojesen-Koefoed, J., Jensen, S. M. \& Stemmerik, L. 1991: Oil seep in basement, Germania Land, NorthEast Greenland. Open File Ser. Gronlands geol. Unders. 91/7, $18 \mathrm{pp}$.

Christiansen, F. G. \& Pulvertaft, T. C. R. 1992: Petroleum geological activites in 1991: reassessment of areas of earlier exploration, and improvement of information service to industry. Rapp. Gronlands geol. Unders. 155, 28-30.

Friderichsen, J. D., Gillotti, J. A., Henriksen, N., Higgins, A. K., 


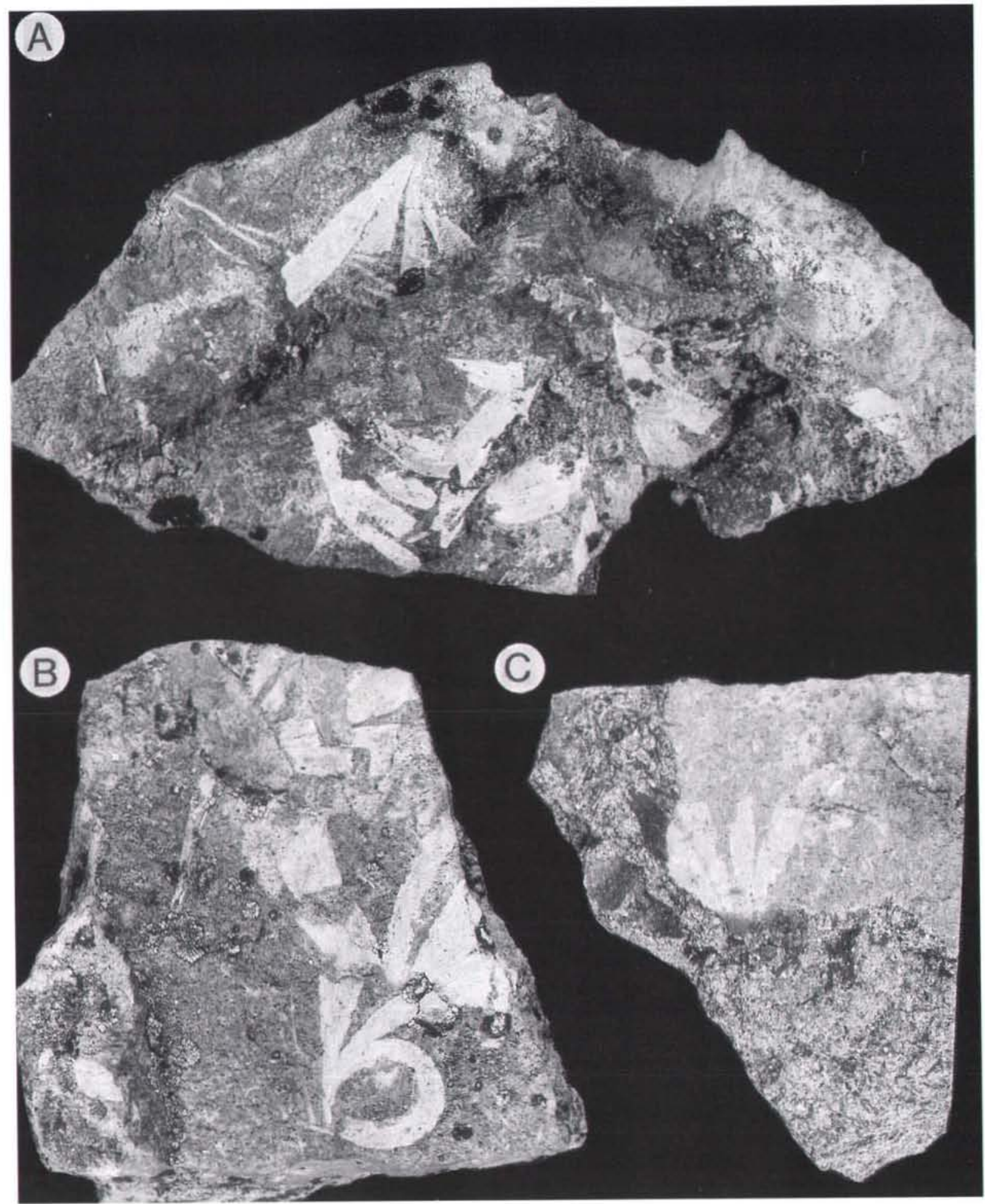

Fig. 4. Imprints of Jurassic fossil leaves of the genus Baiera from the locality north of Kulhøj (GGU 365093) A: $\times 0.75$, B \& C: $\times 1$. 

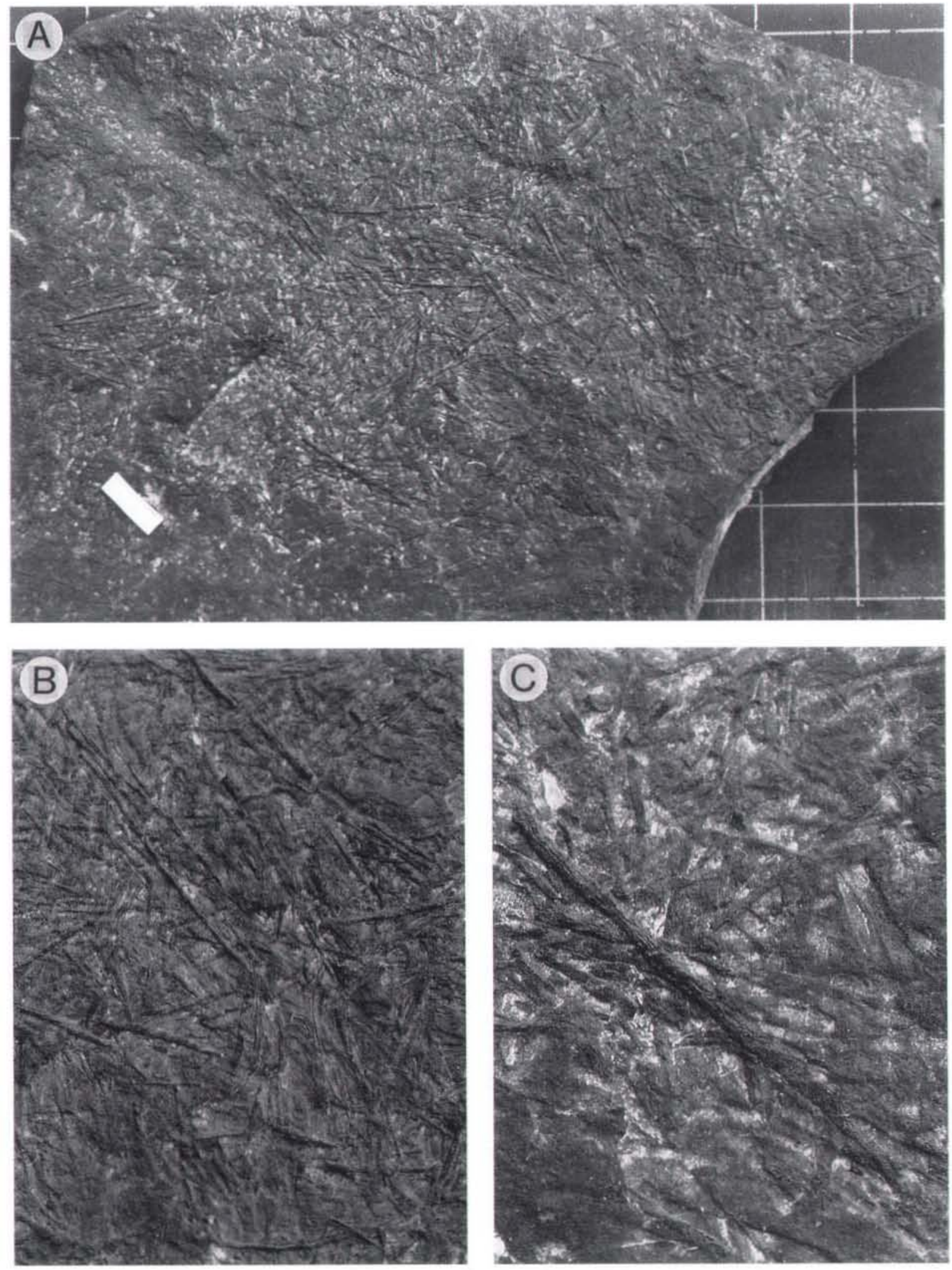

Fig. 5. A: Drift block of coal from the Kulhøj locality with resinous bodies partly stream oriented on the surface $(\times 0.5)$. B: $\times 1.2 \&$ C: $\times 2.3$ (GGU 360381). 
Hull, J. M., Jepsen, H. F. \& Kalsbeek, F. 1991: The crystalline rocks of Germania Land, Nordmarken and adjacent areas, North East Greenland. Rapp. Gronlands geol. Unders. 152, 85-94.

Håkansson, E. \& Stemmerik, L. 1989: Wandel Sea Basin - a new synthesis of the Late Paleozoic to Tertiary accumulation in North Greenland. Geology 17, 683-686.

Harris, T. M. 1935: The fossil flora of Scoresby Sound. Meddr Gronland 112(1), $176 \mathrm{pp}$.

Jensen, S. M. \& Stendal, H. 1994: Reconnaissance for mineral occurrences in North-East Greenland $\left(76^{\circ}-78^{\circ} \mathrm{N}\right)$. Rapp. Gronlands geol. Unders. 162 (this report).

Koch, I. P. 1917: Survey of Northeast Greenland. Meddr Gronland 46(2), 79-468.

Larsen, H. C. 1990: The East Greenland shelf. In Grantz, A., Johnson, L. \& Sweeney, L. F. (ed.) The Arctic Ocean region. The Geology of North America L, 185-210. Boulder, Colorado: Geological Society of America.
Stemmerik, L. \& Piasecki, S. 1990: Post-Caledonian sediments in North-East Greenland between $76^{\circ}$ and $78^{\circ} 30^{\prime} \mathrm{N}$. Rapp. Gronlands geol. Unders. 148, 123-126.

Stemmerik, L., Vigran, J. O. \& Piasecki, S. 1991: Dating of Late Paleozoic rifting events in the North Atlantic: new biostratigraphic data from the uppermost Devonian and Carboniferous of East Greenland. Geology 19, 218-221.

Stemmerik, L., Christiansen, F. G., Piasecki, S., Jordt, B., Marcussen, C. \& Nøhr-Hansen, H. 1993: Depositional history and petroleum geology of the Carboniferous to Cretaceous sediments in the northern part of East Greenland. In Vorren, T. O. et al. (ed.) Arctic geology and petroleum potential. Norweg. Petrol. Soc. Spec. Publ. 2, 67-87.

Surlyk, F. 1990: Timing, style and sedimentary evolution of Late Palaeozoic - Mesozoic extensional basins of East Greenland. In Hardman, R. F. P. \& Brooks, J. (ed.) Tectonic events responsible for Britain's oil and gas reserves. Geol. Soc. Lond. Spec. Publ. 55, 107-125. 